\title{
Obituary: Albano Schwarzbold (1941-2019)
}

\author{
Obituário: Albano Schwarzbold (1941-2019)
}

\section{Fabiana Schneck ${ }^{1 *}$ (D), Sandra Maria Hartz ${ }^{2}$ (D) and Adriano Sanches Melo²}

\begin{abstract}
${ }^{1}$ Instituto de Ciências Biológicas, Universidade Federal do Rio Grande - FURG, Avenida Itália, Km 8, CEP 96203-900, Rio Grande, RS, Brasil

${ }^{2}$ Departamento de Ecologia, Instituto de Biociências, Universidade Federal do Rio Grande do Sul - UFRGS, Avenida Bento Gonçalves, 9500, CEP 91501-970, Porto Alegre, RS, Brasil

*e-mail: fabiana.schneck@gmail.com
\end{abstract}

Cite as: Schneck, F., Hartz, S. M. and Melo, A. S. Obituary: Albano Schwarzbold (1941-2019). Acta Limnologica Brasiliensia, 2020, vol. 32, e7.

Professor Albano Schwarzbold (Ph.D.) died July 17, 2019, after a few months fighting against a cancer. He is survived by his wife, Gilsi, two daughters, Ana Paula and Carolina, one son, Alexandre, and six grandchildren.

Albano was born at March 12, 1941, in Venâncio Aires (district of Mato Leitão), Rio Grande do Sul State (RS), Brazil, where he also attended elementary school. To attend high school (from 1955 to 1958), Albano moved to a nearby city, Santa Cruz do Sul. In 1962 he obtained a certificate of agriculture technician in Viamão, RS, and in 1971 finished his undergraduate studies in Natural History at Universidade do Vale do Rio dos Sinos. During his undergraduate studies he had contact with the work of the naturalist and botanist Priest Balduino Rambo, which greatly influenced him. Meanwhile, he taught at elementary and high schools (1959-1971) and later worked on the interpretation of aerial photography (1972-1976).

In 1977 he got a position as technician at Universidade Federal do Rio Grande do Sul (UFRGS), where he would spend his career until retirement. After three years at the Instituto de Pesquisas Hidráulicas (IPH - UFRGS), Albano got a position as an assistant professor in the Departamento de Zoologia (1981) at the Instituto de Biociências and moved to the recently created Departamento de Ecologia in
1991. His move to the Instituto de Biociências was due to an agreement between UFRGS and the Saarbrücken-GTZ (Germany), during which Albano worked as a scientific technician in limnology between 1979 and 1980. Concomitant to his work as professor, he obtained his Master's degree in Ecology at UFRGS in 1982 under the supervision of Alois Schäfer (Figure 1). His master thesis dealt with the effects of lake morphology and water characteristics on the distribution of macrophytes. Albano obtained in 1992 his Doctorate degree in Ecology and Natural Resources at the Universidade Federal de São Carlos where he worked on the ecology of periphytic communities under the supervision of Francisco de Assis Esteves (Figure 2). Albano retired compulsorily from UFRGS in 2011 after his $70^{\text {th }}$ birthday.

Albano was the head of the Limnology laboratory and taught Limnology and Ecology, among others, to undergraduate students in Biology. He also taught Aquatic Ecology, Ecosystems Ecology and Biogeography and acted as supervisor of Master and Doctorate students at the Programa de Pós-graduação em Ecologia at UFRGS. He mentored eight Doctorate and 21 Master students in Ecology (Figure 3) and many undergraduate students in Biology. In relation to university administration, Albano was the first Head of the Departamento de 
Ecologia (from 1991 to 1993 and reappointed to 1994 and 1995). He also served as the Director of the Centro de Ecologia (UFRGS) in 1997 and 1998.

Albano was one of the pioneering limnologists in south Brazil, publishing more than 40 scientific papers. One of his first and most cited papers, "Origin and morphology of the coastal lakes

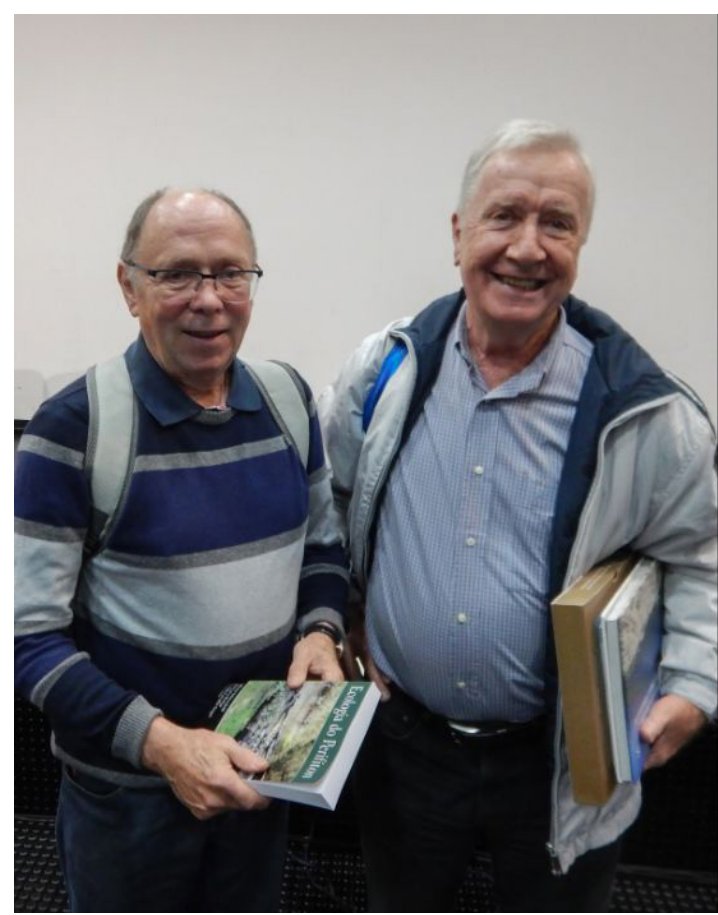

Figure 1. Albano Schwarzbold (right) and Alois Schäfer at the XV Brazilian Limnology Congress in Maringá 2015 (Photo: Alois Schäfer, personal archives). of Rio Grande do Sul”, published in 1984 in Amazoniana in collaboration with Alois Schäfer, is a fundamental work to everyone who studies coastal lakes in Brazil (Schwarzbold \& Schäfer, 1984). In 1986, Albano published a paper in the inaugural volume of the Acta Limnologica Brasiliensia (Schwarzbold et al., 1986) and in 1990 he contributed with an important revision on the ecological methods to study periphytic communities (Schwarzbold, 1990) in a volume of the journal with several papers focused on the study of this group of algae. One of his last scientific contributions was the organization of the book "Ecologia do Perifíton", published in 2013 in collaboration with Lezilda Torgan and Ana Luiza Burliga (Schwarzbold et al., 2013).

In addition to his work in the university, Albano provided expert consulting and participated in many committees to society, such as the Comitê de Ciências Biológicas of the Fundação de Amparo à Pesquisa do Estado do Rio Grande do Sul (1998-2000) and the Comitê de Bacia do rio Taquari-Antas (2003-2010). As one of the pioneering limnologists in Brazil, Albano was also deeply involved in the development of the field in the country, particularly through services in the Associação Brasileira de Limnologia. He acted as treasurer (1987-1988), vice-president (1989-1990) and president (2007-2009). He was the president of the III Brazilian Limnology Congress in 1990, and participated of the organization committee of the XII Brazilian Limnology Congress in 2009. He also

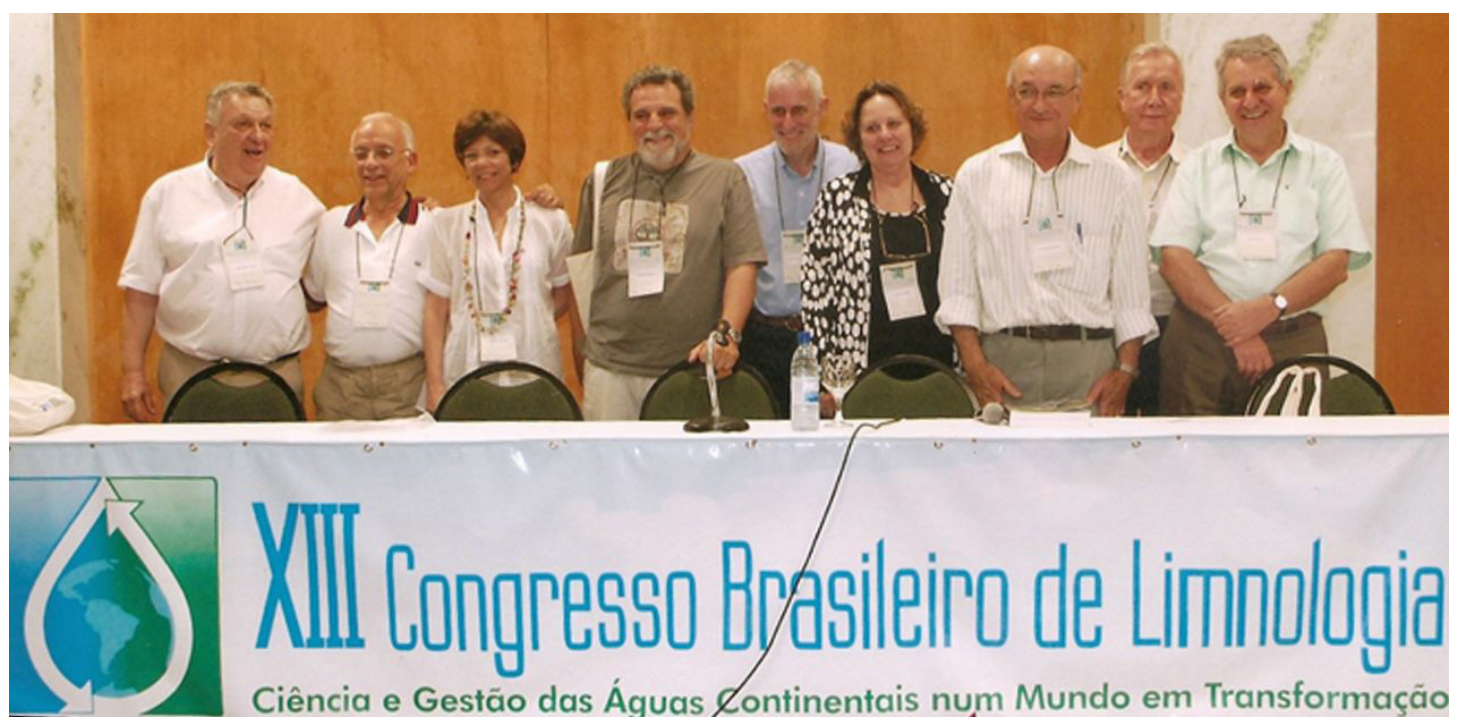

Figure 2. Albano (second from right) with colleagues at the XIII Brazilian Limnology Congress in Natal 2011: José Galizia Tundisi, Carlos Eduardo de Mattos Bicudo, Denise de Campos Bicudo, Francisco Antônio Rodrigues Barbosa, Irineu Bianchini Júnior, Lezilda Carvalho Torgan, Francisco de Assis Esteves, Albano Schwarzbold and Raoul Henry (Photo: Francisco de Assis Esteves, personal archives). 


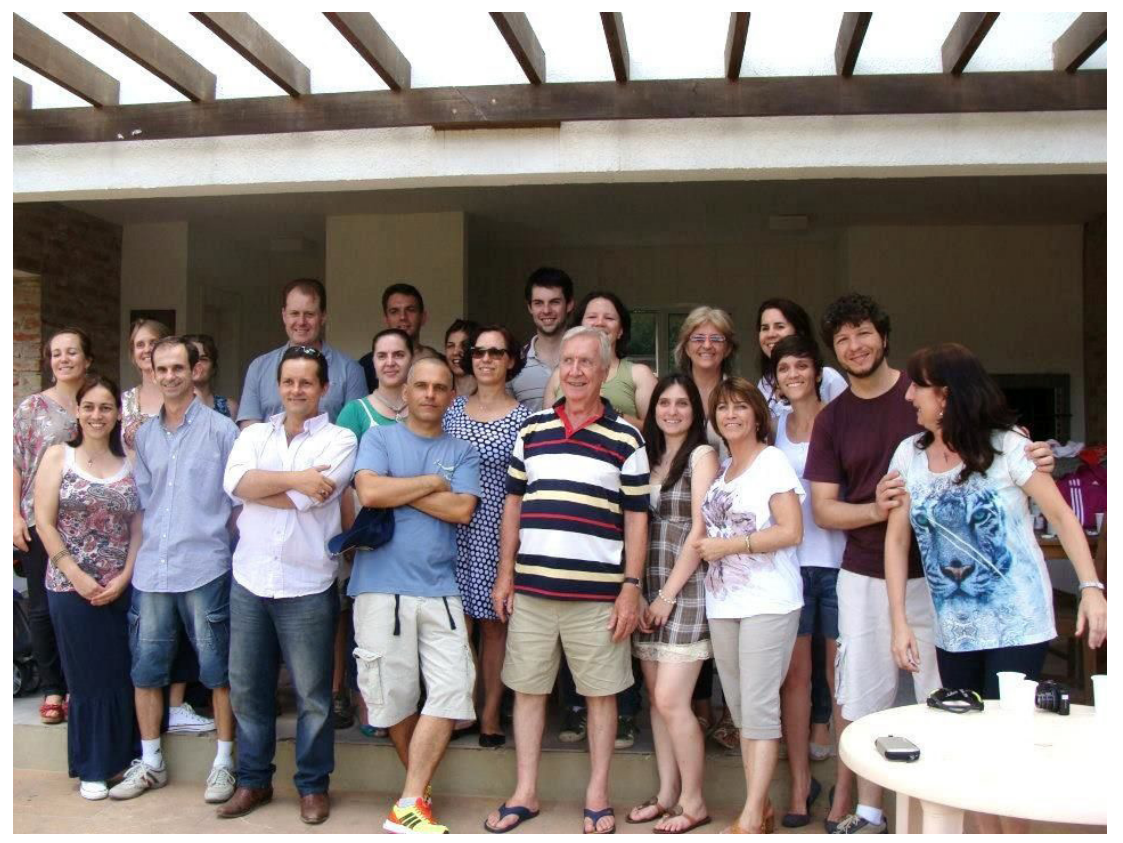

Figure 3. Albano and some of his former students at his home to celebrate his work and retirement, Porto Alegre 2012. (Photo: Fabiana Schneck, personal archives).

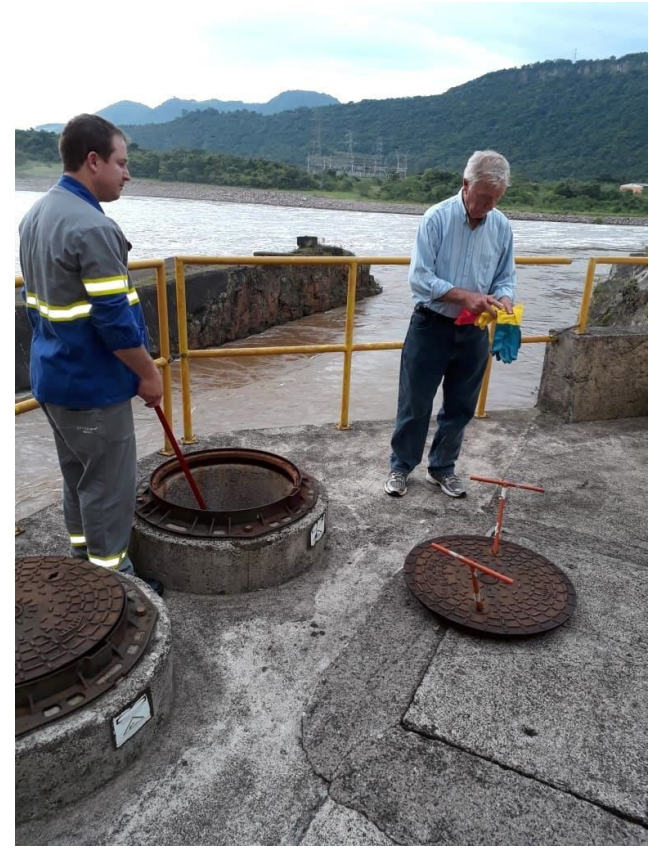

Figure 4. Albano continued to work after his retirement. Here, at Usina Hidrelétrica Dona Francisca, RS (Photo: Margarete Sponchiado).

acted as secretary of the organization committee of the VI Brazilian Meeting on Phycology in 1993.

As a passionate limnologist and educator, Albano did not stop to work even after his retirement. After leaving the Departamento de Ecologia (UFRGS), he worked as an invited Professor at Universidade Estadual do Rio Grande do Sul, where he taught courses for the Especialização em Análise e Manejo de Sistemas Socioecológicos and at the Programa de Pós-graduação em Ambiente e Sustentabilidade. He also continued his work on monitoring water quality in reservoirs (Figure 4) until a few months before his death.

During the 31 years he taught Limnology and Ecology and related courses for undergraduate and graduate students at UFRGS, Albano inspired everyone who met and worked with him. His generosity in sharing knowledge, love for teaching, and enthusiasm in accompanying students in field work and in putting the hands-on in the laboratory will last forever in our memories and hearts.

\section{References}

SCHWARZBOLD, A. Métodos biológicos aplicados ao estudo do perifíton. Acta Limnologica Brasiliensia, 1990, 3(1), 545-592.

SCHWARZBOLD, A. and SCHÄFER, A. Gênese e morfologia das lagoas costeiras do Rio Grande do Sul, Brasil. Amazoniana, 1984, 9(1), 87-104.

SCHWARZBOLD, A., BURLIGA, A.L. and TORGAN, L.C. Ecologia do Perifíton. São Carlos: RiMa, 2013.

SCHWARZBOLD, A., FONSECA, O.J.M. and GUERRA, T. Aspectos limnológicos do Saco de Tapes, Laguna dos Patos. Acta Limnologica Brasiliensia, 1986, 1(1), 89-102.

Received: 08 October 2019 Accepted: 20 March 2020 